\title{
Meta
}

Journal des traducteurs

Translators' Journal

\section{"Translation Studies": Translation in an Undergraduate Setting}

\section{James R. Wheatley}

Volume 41, numéro 3, septembre 1996

URI : https://id.erudit.org/iderudit/004596ar

DOI : https://doi.org/10.7202/004596ar

Aller au sommaire du numéro

Éditeur(s)

Les Presses de l'Université de Montréal

ISSN

0026-0452 (imprimé)

1492-1421 (numérique)

Découvrir la revue

Citer cette note

Wheatley, J. R. (1996). "Translation Studies": Translation in an Undergraduate Setting. Meta, 41(3), 490-494. https://doi.org/10.7202/004596ar
Résumé de l'article

S'appuyant sur son expérience de professeur à l'Université du Queensland, l'auteur démontre qu'une place plus importante devrait être faite à la formation en traduction dans les programmes de langue des universités. Il présente les conditions qui permettraient qu'une formation spécifique en traduction trouve une place vraiment utile au sein de ces programmes. 


\section{‘TRANSLATION STUDIES': TRANSLATION IN AN UNDERGRADUATE SETTING}

\section{Résumé}

S'appuyant sur son expérience de professeur à l'Université du Queensland, l'auteur démontre qu'une place plus importante devrait être faite à la formation en traduction dans les programmes de langue des universités. Il présente les conditions qui permettraient qu'une formation spécifique en traduction trouve une place vraiment utile au sein de ces programmes.

\section{Abstract}

This article draws on the experience of developing and teaching a course on FrenchEnglish translation for third-year students at The University of Queensland. Starting from the assumption that there is a place for specific training in translation within a language programme for undergraduate students, this article seeks to outline the conditions under which the place it might occupy could be a genuinely useful one.

Is there a place for specific training in translation within a language programme for undergraduate students? Starting from the assumption that there is, this article seeks to outline the conditions under which the place it might occupy could be a genuinely useful one. ${ }^{1}$

As is well known, the translation activity which played a central role in traditional language teaching fell into disrepute several decades ago. That it deserved to do so seems undeniable, despite the nostalgia with which many members of a previous generation of students sometimes look back upon it. The pedagogical inadequacy and inappropriateness of such exercises have been discussed elsewhere (see for example Déjean Le Féal 1987 and Ladmiral 1979). It is perhaps enough to remark here that, if at its best the activity led on to insights into a comparative stylistics of the languages involved, translation it was not-if one accepts, as I think one must, that the act of translation necessarily involves the intention to provide a third party (the consumer of the translated text) with "something" (leaving aside, for the moment at least, the question as to what that "something" may in fact be) which would not otherwise be available to that third party. In the traditional exercise, the third party 
was none other than the teacher, to whom the "something" was by definition already and (at least notionally) more fully available than it was to the student doing the "translation;" its only real function seems to have been to act as a means of testing the student's ability to make a close reading of a text in the foreign language (in the case of version) or of evaluating the student's progress towards a certain linguistic correctness (in the case of thème).

Once we decide, however, to take seriously the view that genuine translation is a "making available" and therefore a social act (whatever other, varying concomitant purposes a particular act of translation may have), we are in a position to ask the question posed at the outset, although we may now choose to express it in slightly different terms: can one put the student who is in the process of learning a foreign language in the position of the real life translator, whose job is essentially to make available that "something" to a real life readership, and is there something to be gained, pedagogically, from doing so? Given the communicative approach that has been and continues to be so influential in current language-teaching, the question has begun to be answered in the affirmative, on both counts, and in some detail, by writers such as E. Lavault (1987) and M.-J. Capelle (1987).

Those arguments and proposals are directed at language teaching stricto sensu, and it is not my purpose here to repeat them, but rather to see how translation, rehabilitated, so to speak, by being accorded its true meaning, can be part of an undergraduate modern languages programme which includes not only language courses based on an oral-communicative approach but also important components of textual studies, literary theory and semiotics. While the act of translation as an act of "making available" must play a central part in the type of course envisaged (and indeed does so in the actual course upon which these remarks are based), given the context just outlined such a course would naturally also seek to stand back from the act of translation, in order to see it as a human act and study it in its various dimensions. This is a point which will need to be elaborated later; but it is already clear that a course with such objectives will need a descriptive title that points to those objectives. Hence the term 'translation studies' which I borrow from writers such as James S. Holmes (see Holmes 1978), although, where Holmes intended it to denote a science - the 'pure' and 'applied'-which has translation as its object (a traductologie), my use of it is simply intended to indicate an institutional space, much as in the case of 'gender studies' or 'comparative literature studies.

Having at least established that what is at stake here is not a return to translation in its unredeemed sense, one may now turn to the question of what 'translation studies' may have in common with translator training as such (i.e. the activity of post-graduate students undergoing training as professional translators). There are four principal ways in which this would be so.
(1) All work done is from the language the students are (still) learning (in the case in question, French), into the mother tongue.

(2) (Nevertheless) Work proceeds on the assumption (made explicit) that students have full competence in the source language.

(3) As wide as possible a range of texts is worked on, (ostensibly) purely 'informative' texts included.

(4) All work is done 'as if' it were being done in and for the world outside the classroom, and were responsible to that world.

Each of these four points requires some further comment.

(1) The decision to work only into the mother tongue is generally in line with professional practice. Also, to make the target language of students' still ongoing language courses the target language of translation would be to make unrealistic demands on the students' active command of the foreign language and could only subvert the aims of 'translation studies,' by reinstalling the traditional thème with all its pedagogical implications. Moreover, the prohibition on working into the foreign language, if made quite explicit, itself serves to underline the fact that translation is a difficult, exacting undertaking, one for which only the would-be translator's best resources can hope to be adequate; most students, after all, will come to translation with the naive, lay assumption that a competence in two languages is all that is required to make a translator, and if all "translation studies' did were to disabuse them, in some detail, of this notion, it would surely not be without its raison d'être. A consequence of the decision to work only from the foreign language is that a considerable part of student's activity will consist of a demandingly intimate encounter-sadly, in many cases long-delayed, as experience has shown-with their mother tongue.

(2) If one must guard against the risk of the translation activity central to 'translation studies' reverting to the status of an academic exercise, one needs also to be awrare of the presence of a related, and perhaps more likely danger, namely, that the translation activity might end up as simply another form of language teaching, and one that by its nature would subvert the oral-communicative approach upon which the real language courses being followed by the students are likely to be based. The assumption of total linguistic competence (at first sight surprising, even foolhardy, given that it proposes, after all, to treat undergraduate students as if they were a carefully selected post-graduate group embarking on professional translatorship training) is therefore a tactical one. From the outset a strict distinction needs to be drawn between problems of language competence and problems of translation, the latter being defined as problems which would remain problems however fully competent the translator might be in both source and target language or, 
following Krings (1986), as those situations in which a routine or spontaneous response is not possible and a translation strategy is required. As for language competence problems, students are expected to solve these for themselves, using the variety of resources available-reference books, informants, and so on. This assumes no more than an adequate level of motivation and confines itself to making demands on student's passive command. In practice, 'final drafts' presented by students at seminars rarely show language competence problems that have been left unsolved-where they have been perceived in the first place; the notoriously misleading transparency of French for the English-speaking reader results, as one would expect, in many going unperceived, but they are nevertheless problems of language competence (or here, interlanguage competence) and not problems of translation.

(3) Traditional pedagogical 'translation' concerned itself virtually exclusively with literary texts coften conveniently, if quaintly, divided up into Description, Narrative, Dialogue, etc., see, for instance, Ritchie 1953). Professional translatorship training appears on the whole to regard 'literary translation' as a separate domain lying outside its ambit-a point to which I shall return. An undergraduate translation course can and arguably should afford the luxury of blurring, if not totally ignoring the distinctions involved and of embracing the implications of a Jacobsonian view of language that sees a variety of functions (referential, phatic, expressive, conative, metalinguistic and poetic, to borrow Jacobson's terminology) as potentially present and operative in any utterance or text. No sort of text need be excluded, and texts worked on can vary from instruction manuals, product information brochures, government information leaflets, application forms, hotel information cards, etc. through to texts in which the referential and other functions are joined to a significant degree by an active poetic (in the Jacobsonian sense, i.e. self-reflexive) function, and/or by the metalinguistic function. Texts of this type occur of course in enormous numbers, inhabiting a vast and ill-defined, heterogeneous 'grey area' between the 'informative' and the 'literary' (literary and art criticism, philosophy, linguistics, to name only some of those genres which undergraduates in a languages department are exposed to in any case). Texts belonging to this 'grey area' represent a large proportion of what is actually read and of what finds its way into translation as the common intellectual commerce that goes on between cultures.

As for 'technical' translation proper, the mainstay of the professional translator, the fact that it demands specialised contextual knowledge as much as translatorly skill would seem generally to make it unsuitable for 'translation studies.' However, students studying at the same time another discipline (law, nat- ural sciences, psychology, linguistics, etc.) could be encouraged to undertake translation projects on texts belonging to these areas, and indeed have done so.

(4) If its students slip back into perceiving what they are doing as simply an academic exercise undertaken to satisfy the demands of the teacher and in the vague expectation that it will help them to learn more of the foreign language concerned, an undergraduate translation course would thereby lose the very thing that can provide the most immediate source of motivation for its students, that is, its ability to represent work-in-the-world, a work that not only is made possible by all their other language work (work in the language classroom) but also makes sense of it by giving it an immediate practical application.

A variety of tactics can be adopted to avert this danger. Organising the work of the course around a series of seminars where individual students present a draft translation of a text for the comment and criticism of their fellows (rather than of the teacher-since the teacher is inevitably and necessarily the institutional Other) simulates the 'otherdirectedness,' so to speak, of real-life translators' work. This needs to be made explicit to students from the very beginning. Translation, or rather the 'uttering' of a translation, is a social, indeed a public act; it involves an implied contract between the translator and the new destinataire, to the effect that what was inaccessible to the latter is in some way being made available, so that translators are answerable publicly for what they do, and their work is constantly open to evaluation on that basis.

The importance of this insistence on the contractual nature of translation-making, in other words the explicit refusal of the distinction between classroom and real world, can hardly be overstated. Two practical consequences for the 'translation studies' student are the obligation not to make errors of language competence and the obligation to acquire and apply all the contextual knowledge necessary for a given translation task. A related way of ensuring that work is done as 'work-in-the-world' is to insist that the student routinely consider a series of questions, prior to the actual performance of any translation task; questions such as: Under what circumstances might you be asked to translate this text? For what sort of publication? For what sort of reader? What use would the new reader make of it, and how might that use differ from the use made of the source text by its reader? In what sort of relation to the source text will your translation stand? To all intents and purposes, a total replacement (in the sense most of us commonly mean when we say we have "read War and Peace")? An overt substitute? A means of access to, an aid to the reading of the source text? A scholastic crib? A parallel text with equal status or equal legal force? Such preliminary questions serve not only to reinforce a simulation of the real world; their answers will provide a framework within which decisions that need 
to be made subsequently, in the course of the making of the translation, can be made.

Other activities, peripheral perhaps to the central activity of translation, but none the less important in such an undergraduate course, also help to reinforce the notion of the translator as a publicly practising professional, whose work is open to the public, always potentially evaluatory gaze. Published translations can be studied critically, either in parallel text form or in comparison with a student's previously made draft (the conclusions reached are often surprising, and encouraging!). Reviews of translated texts, where the reviewer comments on the quality of the translation, can be sought out and examined (one rich source of these for French is La Quinzaine littéraire). A third sort of text that repays close study is the text that seeks to lay down guide-lines for the translator as a professional, and most notably the FIT's The Translator's Charter.

Clearly, then, a 'translation studies' course as I have so far described it has much in common, mutatis mutandis, with training in professional translatorship. What differentiates it from professional training, and what protects it from the possible charge of being no more than a low-level, unsystematic imitation is at the same time what is intended to integrate it into an undergraduate modern language programme that includes, as has already been pointed out, not only language-learning but also work on textual studies, semiotics and literary theory. The central aim must of course be to sensitise students to the act of translation, to allow them to experience at first hand and in detail not merely the absence of isomorphy between source and target language but the translator's obligation and struggle to deal with that absence. Equally important, however, is the need to provide ways of enabling students to talk about the act and the experience and the struggle, in other words, ways of 'standing back' from them, to repeat a phrase used earlier.

The need to talk about the act of translation opens up the question of translation theory, since one of the jobs of theory (some would say its only job) is to allow talk to take place, by providing a discourse. Neither an undergraduate 'translation studies' course nor a professional translator course could do its work without at least some theoretical assumptions being shared so as to allow dialogue between student and teacher, and between student and student. But it is likely that the place of theory will differ from one course to the other, if only for the reason that 'translation studies' is, as we have seen, conceived as accompanying and supplementing other, theory-based elements in an undergraduate programme.

There are after all at least three different sorts of discourse that a theory of translation might be asked to provide. (a) It may be seen as essentially explanato$\mathrm{ry}$, that is, as giving an account of what actually happens in the act of translation, of how something gets from source text to target text. (b) It may be seen as much less ambitious, and simply as providing, as systematically as possible, ways of verbalising, and thus of helping with, the difficulties of translation (Ladmiral's discours thérapeutique, as in Ladmiral 1987). (c) Thirdly, it may be seen as providing the framework for a pedagogy of translation.

Typically, in professional translator training, the first and third of these has have been treated as identical: what works as pedagogy is taken to work as a true account of the process of translation. Once this conflation of (a) and (c) is made, (b) (the 'therapeutic discourse'), since it is, as Ladmiral says, a bricolage put together and resorted to in the belief that so far at least we have no such thing as (a), simply drops out of the picture. What makes it possible to claim a relation of identity between (a) and (c) is the adoption of a triadic theory of translation (typically, source text: message, or sens: target text) as opposed to the literalists' (apparently naive) dyad, source text: target text. The triad, as soon as it is posited, implies a process of translation, ${ }^{2}$ an implication made explicit by the arrows which are always a feature of the triad when represented diagramatically (source text - message - target text); in contrast, an arrow, conceivably, might not be thought of as an appropriate symbol of the relation between the two terms of the dyad. To posit a process of transiation is to make a claim to knowledge of what that process is; to know something is to be able to impart it, and so, with the triad, comes a pedagogy. Historically, the triad can be seen as the foundational 'discovery' that permitted translator training as such to come into existence, with all the formalisation and institutionalisation that the notion of training implies.

I shall not rehearse all the arguments for and against a triadic view of translation. I would simply make two points which are relevant to my discussion of what I have called 'translation studies.'

Firstly, in its struggle with its doubters, the triad has generally had to insist that literary texts are different in kind from non-literary texts (given the difficulty of including such things as formal features in the notion of 'message' or - even - of sens) and has thus (again generally) restricted its translator training, the application of its pedagogy, to the translation of 'informative' or 'technical' texts. 'Literary translation' thus remains a sort of no man's land, entry to which requires special (unexplained) talent, though triadists are not incapable of making a foray into it when the doubters' back are turned (see for example, Seleskovitch $1988^{3}$ ). Translation studies, as we have seen, need not observe such a distinction between the literary and the non-literary; to bracket out 'literary translation' would in fact not only be to impoverish 'translation studies' but would be to frustrate it in its overall purpose.

My second point has to do with that overall purpose. Given that 'translation studies' will use translation theory as enabling a discourse but will also seek to look at translation theory as theory (to set up a 'metatheoretical' discourse), we are free to retain the tripartite distinction I have attempted to make among the sorts of discourse made possible by translation 
theory. In other words there is no reason which 'translation studies' should not be openly - though critically-eclectic. Where a student is working on a predominantly informative text, it would seem appropriate to have available a (triadic) process-model such as that of D. Gile (1986), which allows the translator to follow a series of (apparently) discrete, welldefined steps and when necessary to retrace them. And it would be foolish not to make use of the power of the traduction interprétative model to deal with the naïve (Iiteral, as opposed to literalist) procedure of item-matching, of dogged transcoding at the signifier level which most students embarking on 'translation studies' can be expected to think of as translation. On the other hand, where, for example, a student is presenting for class discussion an advanced draft translation of a text whose metalinguistic or whose poetic function is prominent enough to be the source of problems which an appeal to the text's 'message' will not make go away, one can switch from a 'processoriented' to a 'problem-oriented' approach which has more in common with Ladmiral's traductothérapeutique. The objects of this particular discourse are less likely to be problems of translation in general than they are to be translation problems which inhabit, so to speak, the particular interlinguistic region defined by the two languages involved: in the French-English case, for example, the absence in English of the overt and systematic signalling of event versus circumstance in French narrative, via the imparfait and the passé simple; or the extreme polysemy of lexical items such as, notoriously, French jeu and rêve. Such a discourse is theoretical, to the extent that it attempts to generalise, to classify, to describe a problem as clearly and explicitly as possible, to find points of comparison between it and problems already encountered, to seek its solution in the ways those past problems were solved, if indeed they were solved. Lastly, since 'translation studies' seeks to treat translation both as something which needs to be done and as something which needs to be talked about, and treats talk about translation as talk in which the last word is far from having been said, such switches of 'approach' will not be made covertly, but will be drawn to students' attention, together with the contradictions they imply.

JAMES R. WHEATLEY

The University of Queensland, Brisbane, Australia

Notes

1. This article draws on the experience of developing and teaching a course on French-English translation for third-year students in the Department of Romance Languages at The University of Queensland.

2. Whether or not a non-triadic theory of translation can talk in terms of $a$ translation process (one with a global application) is unclear to me. At first sight, Krings' "tentative model of the translational process" (1986: 269) looks like an attempt to do this. However, in its attempt to classify and chart the various strategies available to deal with translation problems (defined by Krings, as we have seen, as those situations where a translational strategy is needed because direct, automatic transformation is not possible), it is much closer to the problem-oriented, 'therapeutic' discourse envisaged by Ladmiral than it is to, say, Gile's processmodel. The classical, thorough-going version of the (triadic) process-theory, after all, denies that such things as translation problems exist, by pre-empting them.

3. Seleskovitch's main purpose in her paper is to show that compléments cognitifs (the cognitive co-text plus world-knowledge) play the same part in both literary and technical translation. However, in her treatment of the Sassoon poem she uses as an example, she equates the aim of recommunicating the sense of a technical text with that of replicating the 'impact on the reader' of a literary text. The questions raised (or begged) by such an approach would, under the general question of the notion of 'fidelity' have to be objects of discussion in the sort of 'translation studies' course this article has in mind.

\section{REFERENCES}

CAPELLE, Marie-José (1987): "Un pas vers la traduction interprétative", Le français dans le monde, numéro spécial: Retour à la traduction, août-septembre, pp. 128-135.

DÉJEAN LE FÉAL, Karla (1987): "Traduction pédagogique et traduction professionnelle", Le français dans le monde, numéro spécial: Retour à la traduction, août-septembre, pp. 107-112.

DELISLE, Jean (1981), "De la théorie à la pédagogie", J. Delisle (Ed.), L'enseignement de l'interprétation et de la traduction: de la théorie à la pédagogie, University of Ottawa Press, pp. 135151.

GILE, Daniel (1987): "An Operational Model of Translation", Japan Association of Translators' Bulletin, 24, march, pp. 4-5.

HOLMES, James S. (1978): "Translation Theory, Translation Studies, and the Translator", Translation, A Profession, Proceedings of the $8^{\text {th }}$ World Congress of the International Federation of Translators, Montreal, pp. 55-61.

KRINGS, Hans P. (1986): "Translation Problems and Translation Strategies of Advanced German Learners of French", J. House, and S. Blum Kulka (Eds.), Interlingual and Intercultural Communication: Discourse and Cognition in Translation and Second Language Acquisition Studies, Tübingen, Günter Narr, pp. 264-275.

LADMIRAL, Jean-René (1979): Traduire: théorèmes pour la traduction, Paris, Payot.

LADMIRAL, Jean-René (1987): "Traductologiques", Le français dans le monde, numéro spécial: Retour à la traduction, août-septembre, pp. 18-25. 
LAVAULT, Élisabeth (1987): "Traduction pédagogique ou pédagogie de la traduction", Le français dans le monde, numéro spécial: Retour à la traduction, août-septembre, pp. 119-127.

RITCHIE, R. L. G. (1953): A New Manual of French Composition, Cambridge University Press.

SELESKOVITCH, Danica (1988): "Technical and Literary Translation: a Unifying View", Proceedings of the Second Annual Conference of the Institute of Translation and Interpreting, April 1988, pp. 83-88. 